\title{
Yansıtıcı Düşünme Odaklı Bir Çevrimiçi Ortamın Oluşturulması ve Etkililiğinin İncelenmesi $^{1}$
}

\author{
Tansel Tepe ${ }^{2}$, Naşide Işık ${ }^{3}$, Kerem Ay ${ }^{4}$, Mukaddes Erdem ${ }^{5}$
}

\begin{abstract}
$\ddot{O} z$
$\mathrm{Bu}$ çalışma yansıtıcı düşünme becerilerini harekete geçirecek, becerilerin kullanılmasını ve geliştirilmesini sağlayacak bir çevrimiçi ortam oluşturmak ve bu ortamın etkililiğini incelemek üzere gerçekleştirilmiştir. Sınıf yönetimi ders içeriğine göre hazırlanan bu araştırmada nicel ve nitel yöntemlerin birlikte kullanıldığı karma desenlerden açımlayıcı sıralı desen kullanılmıştır. Uygulama sürecine başlamadan önce 12 üniversite öğrencisi ile araştırmanın pilot uygulamas1 gerçekleştirilmiştir. Pilot uygulama sonuçlarına göre çevrimiçi ortamın öğrencilerin yansıtıcı düşünebilme becerilerini geliştirebileceğine dair ipuçları elde edilmiştir. Pilot uygulama sonunda öğrencilerden alınan görüşler doğrultusunda çevrimiçi ortamda düzenlemeler yapılmış ve düzenlenen yeni çevrimiçi ortam, araştırmaya gönüllü katılan 30 üniversite öğrencisi üzerinde yeniden sınanmıştır. 30 öğrenciden toplanan nicel ve nitel veriler analiz

\footnotetext{
${ }^{1}$ IX. Uluslararası Bilgisayar ve Öğretim Teknolojileri Eğitimi Sempozyumu'nda sunulan bildirinin gözden geçirilmiş ve genişletilmiş halidir. tanseltepe@kilis.edu.tr

${ }^{3}$ Yüksek lisans öğrencisi, Hacettepe Üniversitesi, Eğitim Fakültesi, Bilgisayar ve Öğretim Teknolojileri Eğitimi Bölümü, naside.isik@gmail.com

${ }^{4}$ Yüksek lisans öğrencisi, Hacettepe Üniversitesi, Eğitim Fakültesi, Bilgisayar ve Öğretim Teknolojileri Eğitimi Bölümü, kerem.ay.125@gmail.com

${ }^{5}$ Prof. Dr., Hacettepe Üniversitesi, Eğitim Fakültesi, Bilgisayar ve Öğretim Teknolojileri Eğitimi Bölümü, mukaddese@gmail.com

Geliş tarihi / Received: 10.10.2015, Kabul tarihi / Accepted: 29.06.2016
}

${ }^{2}$ Araş. Gör., Kilis 7 Aralık Üniversitesi, Eğitim Fakültesi, Bilgisayar ve Öğretim Teknolojileri Eğitimi Bölümü,
\end{abstract}


edildiğinde çevrimiçi ortamın öğrencilerin yansıtıcı düşünebilme becerilerine katkı sağladığı sonucuna varılmıştır.

Anahtar Sözcükler: Yansıtıcı düşünme, çevrimiçi tartışma ortamları, yapılandırmacı öğrenme 


\title{
Developing a Reflective Thinking Focused Online Environment and Investigation Its' Effectiveness
}

\begin{abstract}
This study has been carried out to develop an online environment that will trigger reflective thinking skills and that will enable the use and improvement of these skills. Sequential Explanatory Design, one of the mixed designs in which quantitative and qualitative methods are used together, has been used in this study prepared according to the curriculum of Class Management. Before starting the implementation process, a pilot scheme of the study with twelve university students has been carried out. According to the results of the pilot scheme, some clues showing that online environment may improve the reflective thinking skills of the students have been found. At the end of the pilot scheme, a few arrangements have been made online in the direction of the students' views and this new arranged online environment has been retested on the thirty volunteer university students. When the qualitative and quantitative results collected from the thirty volunteer students were analyzed, it was concluded that the online environment made a contribution to the reflective thinking skills of the students.
\end{abstract}

Keywords: Reflective thinking, online discussion environment, constructivism learning 


\section{Giriş}

Bireylerin kendi süreçleri üzerine düşünüp, düşündüklerini ifade edebilmeleri yansıtıcı düşünme faaliyeti altında ele alınabilir. Dewey’e (1991) göre yansıtıcı düşünme, bilgi ya da bilginin amaçladığı sonuçlara ulaşmayı destekleyen bir bilgi yapısını dikkatli, tutarlı ve etkin bir biçimde düşünmedir. Düşünmeden kaynaklı kuşku, tereddüt, şaşkınlık ve zihinsel zorluk durumu ile bu kuşkuyu, şaşkınlığı ve zorluğu gidermek için araştırma ve sorgulamayı içermesi yansıtıcı düşünmeyi diğer düşünme şekillerinden ayıran özellikler olarak belirtilmiştir. Dewey (1991), bireylerin yansıtıcı düşünebilmeleri için sadece bilmelerinin yetmediğini, bireylerin istek duymasının ve yansıtıcı düşünmeyi olanaklı kılacak açık görüşlülük, içtenlik ve sorumluluk gibi tutumlara sahip olması gerektiğinin önemini vurgulamaktadır. Açık görüşlülük, bireyin zihnini yeni düşüncelere, sorunlara ve çözümlere kapatan önyargı ve taraflılıktan uzak durması; içtenlik, yenilikler yapma konusunda güçlü bir istek ve içten bir ilgiye sahip olma; sorumluk ise kişinin eylemlerinin sonuçlarını dikkate alması gerektiğidir.

Yansıtıcı düşünme problem, öneriler, hipotez, akıl yürütme ve test etme basamaklarından oluşmaktadır. Problem basamağında, hissedilen ya da deneyimlenen zorluğun ifadesi; öneriler basamağında, olası çözümleri içeren öneriler sunulması; hipotez basamağında, verilen bir önerinin nasıl kullanılması gerektiği; akıl yürütme basamağında, bilgi, fikir ve önceki deneyimlerin birbiriyle bağlantısı ve test etme basamağında, hipotezin kabul veya reddedilmesi ele alınmaktadır (Dewey, 1991). Yansıtıcı düşünme sürecini Schön (1983), eylem içi yansıtma (reflection in action) ve eylem üzerine yansıtma (reflection on action) olmak üzere iki biçimde ele almıştır. Eylem içi yansıtma, kişinin eylem sırasında eyleme dönük düşünmesi olarak tanımlanırken; eylem üzerine yansıtma, kişinin eylemleri üzerine sistematik ve kasıtlı düşünmesi olarak tanımlanmıştır. Ayrıca Schön (1983), sadece yaparak düşünmeye değil, bir şey yaparken onun hakkında düşünebilmeyi de yansıtıcı düşünme kapsamına almaktadır.

Dewey'in 1srarla vurguladığı gibi yansıtıcı düşünme planlı ve kontrollü bir düşünme becerisidir ve geliştirilmesi gereken bir yapıdadır (Rodgers, 2002). Yansıtıcı düşünme becerisinin geliştirilmesi amacıyla bir takım etkinlikler kullanılmaktadır ve bu bağlamda kullanılan etkinliklerden biri de tartışmadır (Ünver, 2003; Taggart ve Wilson, 2005). Sınıf ortamında sözlü anlatım şeklinde işlenen derslere ek olarak sunulan ya da doğrudan çevrimiçi süreçlerde başlatılan tartışmalarla öğrencilerin kendi öğrenmelerini yapılandırmaları ve yeni düşünme biçimleri geliştirmeleri sağlanabilir. Çevrimiçi tartışma ortamlarında öğrenenler kendi 
anlamlarını yapılandırmakta, etkinlikleri açıklamakta, farklı bakış açıları geliştirmekte, var olan farklı görüşleri kıyaslamakta ve bu görüşler üzerine düşünerek yansıtıcı ve eleştirel düşünme yetilerini geliştirmektedirler (Jorgensen, 2002). Çevrimiçi tartışmaların öğretmen adaylarının gelişiminde tamamlayıcı bir rolü olduğunu savunan Nicholsan ve Bond'a (2003) göre, çevrimiçi tartışmalar, öğretmen adaylarına zaman ve mekân açısından yarar sağlamakta, duygusal, zihinsel desteğe ve topluluk hissine teşvike katkıda bulunmakta ve yansıtmayı desteklemektedir (Ramos Hernandez, 2004). Çevrimiçi tartışma ortamlarının kullanımı, öğrencilere kendilerinin ve diğer öğrencilerin cevaplarını dikkatlice inceleyip, değerlendirmeleri için zaman sunduğundan öğrencileri yalnız çalışmalarından daha çok yansıtmaya teşvik etmektedir (Salmon, 2002).

Yansıtıcı düşünmeyi tetikleyen çevrimiçi tartışma ortamlarının belirli özelliklere sahip olması gerekmektedir. Bu noktada da yansıtıcı düşünme açısından çevrimiçi tartışma ortamlarının özelliklerinin tartışılması önem kazanmaktadır. Revill ve Terrell'e (2005) göre, canlı ve aktif tartışmalar yaratmak için, tartışma forumları uygun bir şekilde planlanmış ve yönetilebilir olmalıdır. Çevrimiçi tartışma ortamlarında öğrenci katılımını artıran etmenler de önemlidir. Hew ve Cheung'e (2008) göre, eş zamansız çevrimiçi tartışmalara öğrenci katılımını sağlamanın en etkili iki yolu öğrencilere tartışma içinde sorgulama yaptırma ve kendi deneyimlerini ve düşüncelerini paylaşma fırsatı vermektir. Çalışmada ayrıca çevrimiçi tartışma ortamlarına öğrenci katılımının yansıtıcı, kritik düşünme üzerine etkilerinin araştırılması gerektiği de vurgulanmıştır. McNamara ve Brown (2008), çevrimiçi tartışma ortamlarında dikkat edilmesi gereken üç maddeyi forumun organizasyonu, motivasyon ve öğrencilerin etkin katılımı olarak belirtmişlerdir. Bunun yanında açık uçlu çok boyutlu bir tartışma konusunun, öğrencilerin önceki deneyimlerinin üzerine inşa edilmesine ve kendi öğrenmelerini diğer öğrencilerin bakış açılarına göre geliştirmeye teşvik ettiğine ve iyi organize edilmiş bir tartışma ortamının öğrencilerin yansıtıcı düşünmelerini geliştirebileceğine vurgu yapmışlardır.

Yansıtıcı düşünme becerisinin geliştirilebilir bir yapıda olduğu gerçeği, bu becerinin ölçümünün nasıl yapılabileceği bilgisini de önemli kılmaktadır. Alanyazın incelendiğinde, yansıtıcı düşünme becerisinin genellikle ölçekler yoluyla ölçüldüğü dikkati çekmektedir. Ancak alanyazında çevrimiçi tartışma ortamlarında yansıtıcı düşünme becerisinin geliştirilmesine odaklanan ve çevrimiçi tartışma yoluyla toplanmış yazılı ifadelerin ölçülmesinde ise dereceli puanlama anahtarları (rubrikler) veya içerik analizleri kullanılmıştır. Özçınar (2009) tarafından video durumların uzman yorumlarıyla zenginleştirilmesinin ve 
video durumların tartışılması için oluşturulan çevrimiçi tartışmalarda öğretmen adayları ile öğretmenlerin birlikte bulunmalarının, öğretmen adaylarının yansıtıcı düşünme düzeylerine etkisini belirlemek amacıyla yapılan çalışmada, video durumlar izletilmiş ve ardından eşzamansız çevrimiçi tartışmalar başlatılmıştır. Çevrimiçi tartışmadan elde edilen mesajlar, içerik analizi ile incelenmiştir. Araştırmanın sonunda; çevrimiçi tartışma gruplarındaki öğretmen katılımının yansıtıcı düşünme düzeyine anlamlı bir etki yaratmadığı sonucuna ulaşılmıştır. Makoul, Zick, Aakhus, Neely ve Roemer (2010) tarafından yapılan bir çalışmada, tıp alanındaki öğrencilerin iletişim konusundaki yansıtmalarını teşvik etmek için çevrimiçi bir forum kullanılmıştır. Forumda yansıtmayı teşvik edecek, açık uçlu tartışma soruları oluşturulmuştur. Tartışma sorularına verilen cevaplar, içerik analizi ile incelenmiş ve araştırmanın verileri elde edilmiştir. Araştırmadan elde edilen sonuçlara göre, çalışma kapsamında kullanılan çevrimiçi forum, yansıtmayı desteklemiştir. Mettiainen ve Vahamaa (2013), yansıtıcı web tabanlı tartışmalar oluşturarak hemşirelik bölümündeki öğrencilerin öğrenme deneyimleri geliştirilmeye çalışmıştır. Çalışmada, üçüncü sınıftaki hemşirelik öğrencileri ile sekiz haftalık çevrimiçi tartışmalar yürütülmüştür. Öğrencilerin deneyimlerini açıklayabilmeleri için tartışma içerisine yönlendirici sorular eklenmiş ve öğretici tartışmaları takip edilip öğrencilerin ihtiyaç duyduğu bölümlerde dönütler sağlamıştır. Çevrimiçi tartışmalardaki mesajlar, içerik analizi ile incelenmiştir. Araştırmada, akran desteğinin önemi vurgulanırken, bu uygulama ile öğrencilerin yansıtıcı düşünme süreçlerinin de geliştiği raporlanmıştır.

Yansıtıcı düşünme becerisi geliştirmede bir takım etkinliklerin kullanıldığı çalışmalar olmasına rağmen doğrudan çevrimiçi tartışmaların yansıtıcı düşünmeye etkisinin incelendiği çok sayıda çalışmaya erişilememiştir. $\mathrm{Bu}$ doğrultuda bu çalışmanın alanyazına katkı sağlayacağı düşünülmektedir. Bu çalışmada; içeriği sınıf yönetimi dersinden alınan bir çevrimiçi tartışma ortamı tasarlanmış, ortamda yürütülen tartışmalarla katılımcıların yansıtıcı düşünme becerileri geliştirilmeye çalışılmış ve ortamın öğrencilerin yansıtıcı düşünebilme becerileri üzerine etkisi incelenmiştir. Çalışmanın amacı doğrultusunda aşağıdaki araştırma sorularına yanıtlar aranmıştır:

1. Geliştirilen çevrimiçi ortam öğrencilerin yansıtıcı düşünme becerileri üzerinde anlamlı bir etki yaratmakta mıdır?

2. Geliştirilen çevrimiçi ortama yönelik öğrenci görüşleri nelerdir? 


\section{Yöntem}

\section{Desen}

$\mathrm{Bu}$ çalışmada karma desenlerden açımlayıcı sıralı desen kullanılmıştır. Karma desenlerde, nitel ve nicel veriler tek bir araştırmada toplanmakta, analiz edilmekte ve yorumlanmaktadır (Onwuegbuzie ve Leech, 2006). Açımlayıcı sıralı desene göre öncelikle nicel veriler, daha sonra nitel veriler toplanmaktadır. Ayrıca, nicel verilere vurgu yapılmakta olup, nitel veriler nicel verileri destekleyici konumdadır (Creswell, 2003). Bu çalışmada öncelikle nicel veriler daha sonra ise nitel veriler toplanmış ve nitel veriler nicel verileri açıklamak amacıyla analiz edilip, yorumlanmıştır.

\section{Katılımcilar}

Çalışma, pilot uygulama ve nihai uygulama olarak iki aşamada gerçekleştirilmiştir. Oluşturulan çevrimiçi ortamın pilot uygulaması farklı üniversitelerden 12 öğrenci, nihai uygulaması ise farklı üniversitelerden 30 öğrenci üzerinde yürütülmüştür. Üniversite öğrencilerinin yaşları 18 ile 30 arasında değişiklik göstermektedir. Çalışmanın pilot uygulamasına altı erkek ve altı kadın; nihai uygulamasına ise yedi erkek ve 23 kadın öğrenci katılmıştır. Öğrenciler araştırmaya tamamen gönüllü olarak katılım göstermiştir. Pilot ve nihai uygulama sonrası çevrimiçi ortama yönelik nicel veriler bu öğrencilerin öntest-sontest puan ortalamaları üzerinden, nitel veriler ise görüşleri üzerinden analiz edilmiştir.

\section{Çevrimiçi Ortam ve Geliştirilme Süreci}

Çalışmada üniversite öğrencilerin yansıtıcı düşünme becerilerini harekete geçirecek, becerilerini kullanmalarını ve geliştirmelerini sağlayacak bir çevrimiçi ortam oluşturulmuştur. Oluşturulan çevrimiçi ortam, http://yansiticidusun.net/ web sitesi üzerinden yayınlanmış olup, ortamın oluşturulmasında Jonassen'ın (1999) yapılandırmacı öğrenme ortamı tasarım modeli temel alınmıştır. Bu modele göre yapılandırmacı bir öğrenme ortamı,

- Öğrenen etkinlik ve manipülasyonuna açık olmalı, (aktif / manipülatif)

- Bireyin yapılandırmacı doğasını dikkate almalı, (yapılandırmacı) 
- İşbirlikli çalışmaları ve öğrenenler arası sözel paylaşımları desteklemeli, (işbirliği ve iletişim)

- Bireyi kendi süreçleri üzerinde düşünmeye ve bunları ifade etmeye teşvik etmeli, (yansitic1)

- Gerçeğin karmaşık doğasını hesaba katmalı, (kompleks)

- Amaçlı ve anlamlı gerçek problemler üstünde durmalıdır (amaçlı ve bağlamsal) (Arkün ve Erdem, 2007; Jonassen, 1999).

Jonassen'ın yapılandırmacı öğrenme ortamları tasarım modeline göre öğrenme süreçleri, amaçlı ve anlamlı gerçek problemler üzerinde durmalı; gerçeğin karmaşık doğasını hesaba katmalıdır. Buradan hareketle geliştirilen bu çevrimiçi ortamda katılımcıların ilgisini uyandırmaya yönelik gerçek sınıf problemleri katılımcı grubuna sunulmuş ve katılımcıların probleme ve problemlerin çözümüne ilişkin tartışmaları ile fikir geliştirmeleri beklenmiştir.

Problemler, araştırma kapsamında ve pilot uygulama öncesinde katılımcılara verilen açık uçlu sınıf yönetimi sorunları anketine dayalı olarak ya da araştırmacıların doğrudan kendi yaşadıkları sınıf sorunlarından hareketle oluşturulmuştur. Böylece hem problemler gerçek ortamdan bağlamıyla birlikte alınabilmiş, hem de katılımcıların verilen problem durumlarını sahiplenmelerini ve kendi süreçleri üzerine düşünmelerini kolaylaştırmıştır. Böylece yansıtıcı düşünme süreçlerinin harekete geçirildiği ortamda katılımcıların, diğer katılımcıların önerilerine uzlaşmacı ya da karşıt görüşler üretmeleriyle sosyal yapılandırmacı bir dinamik yakalanmıştır.

Öğrencilere, tartışma ortamında problem durumlarına çözüm önerilerini dile getirirken ve duruma yönelik rahatsız oldukları problemleri paylaşırken ayrı başlıklar açma ve aynı problemi hisseden diğer öğrencilerle tartışma olanağı sunulmuştur. Böylelikle öğrenene problem durumunu ve ortamı etkileyebilecek manipülasyon yetkisi verilmiştir.

Çevrimiçi ortam, forumda yorum yazarken ses, video ve resim eklentilerine imkân tanımaktadır ve yapılan yorumlar hiyerarşik şekilde alt alta sıralanmaktadır. Yorum yaptığı başlığa yeni bir yorum geldiğinden haberdar olmak isteyen öğrenciler için çevrimiçi ortamda bildirim seçeneği mevcuttur. Öğrencinin bu seçeneği işaretlemesiyle birlikte gelen her yeni 
yorumda öğrenciye bildirim gitmektedir. Böylece tartışmaları takip etmek ve katılıma süreklilik kazandırmak olanaklı olmaktadır.

Çalışmasındaki tartışma konuları olan video durumlar içerisine öğrencilerin duruma farklı bakış açılarından bakma olanağı sağlayan yansıma noktaları ekleyerek, bu durumun yansıtıcı düşünmeye olumlu bir etki yarattığını ifade eden Özçınar (2009)'a göre:

"Yapılandırmacı yaklaşımın savlarıyla bakıldı̆̆ında, durumların farklı bakış açılarından tartışılmasının öğrenmeyi zenginleştirmesi olanaklıdır. Buna göre, durum ögretmeni ve uzmanlar tarafindan yapılan yorumları da içerecek biçimde oluşturulan durumlar, ögretmen adaylarına durumla ilgili farklı deneyimlere sahip olan ve duruma farklı biçimlerde yaklaşan kişilerin bakış açılarından haberdar olma ve bu farklı bakış açılarını tartışma olană̆ı sağlayacaktır.” (s. 31)

Dolayısıyla bu çalışmada problem durumlarının hemen ardından yönlendirici sorular eklenmiş ve tartışmalar esnasında da yönlendirmeler yapılarak katılımcıların, problem durumlarındaki farklı kişiler tarafından olaya bakmaları ve çözüm önerilerini geliştirirken başvurabilecekleri kuramsal bilgiler vurgulanmıştır. Ayrıca problemin hemen ardından gelen yönlendirici sorular, öğrenenin yansitıcı düşünme aşamalarına uygun düşünme süreci geçirmesi için öğreneni destekleyecek bir yapıda hazırlanmıştır. Tartışmalar, araştırmacılar tarafından takip edilmiş ve tartışmanın gidişatına göre doğru zamanlarda yönlendirmeler yapılmıştır.

Çevrimiçi ortamda öğrenenlerin problem durumlarını tartışırken ihtiyaç duyduğu anda başvurabileceği bilgi kaynakları yer almaktadır. Kaynaklar, detaylı bilgi verilmeden öğreneni araştırmaya teşvik edecek şekilde oluşturulmuştur. Çevrimiçi ortamda bir problem anında öğrenenlere destek için çevrimiçi yardım ve iletişim butonları eklenmiştir.

\section{Tasarım ve Pilot Uygulama}

Wordpress içerik yönetim sistemi kullanılarak tasarlanan ortamda "WP-LMS" temas1 kullanılmıştır. Anasayfada öğrencileri görsel olarak motive edebilmek ve ortamla ilgili bazı açıklamalara dikkat çekebilmek için animasyonlu resim geçişleri kullanılmıştır. Pilot uygulama bir hafta sürmüş olup pilot uygulamaya yönelik ekran görüntüsü şekil 1'de gösterilmiştir. Genel anlamda anasayfa dört temel bölümden oluşmaktadır. Bunlar: Sınıf yönetimi ile ilgili örnek olayların yer aldığı Problem Durumları, öğrencilerin herhangi bir tartışma ortamına girmeden önce ilk problem durumuna ilişkin çözümlerini kaydedebilecekleri Çözüm Taslakları, verilen 
problem durumlarını diğer kullanıcılarla tartışabilecekleri Forum ve sınıf yönetimine dair modellerle ilgili giriş bilgileri bulabilecekleri Sınıf Yönetimi İçerikleridir. Bunların dışındaki menüler: Hakkımızda, İletişim ve Sık Sorulan Sorular (SSS)'dır.

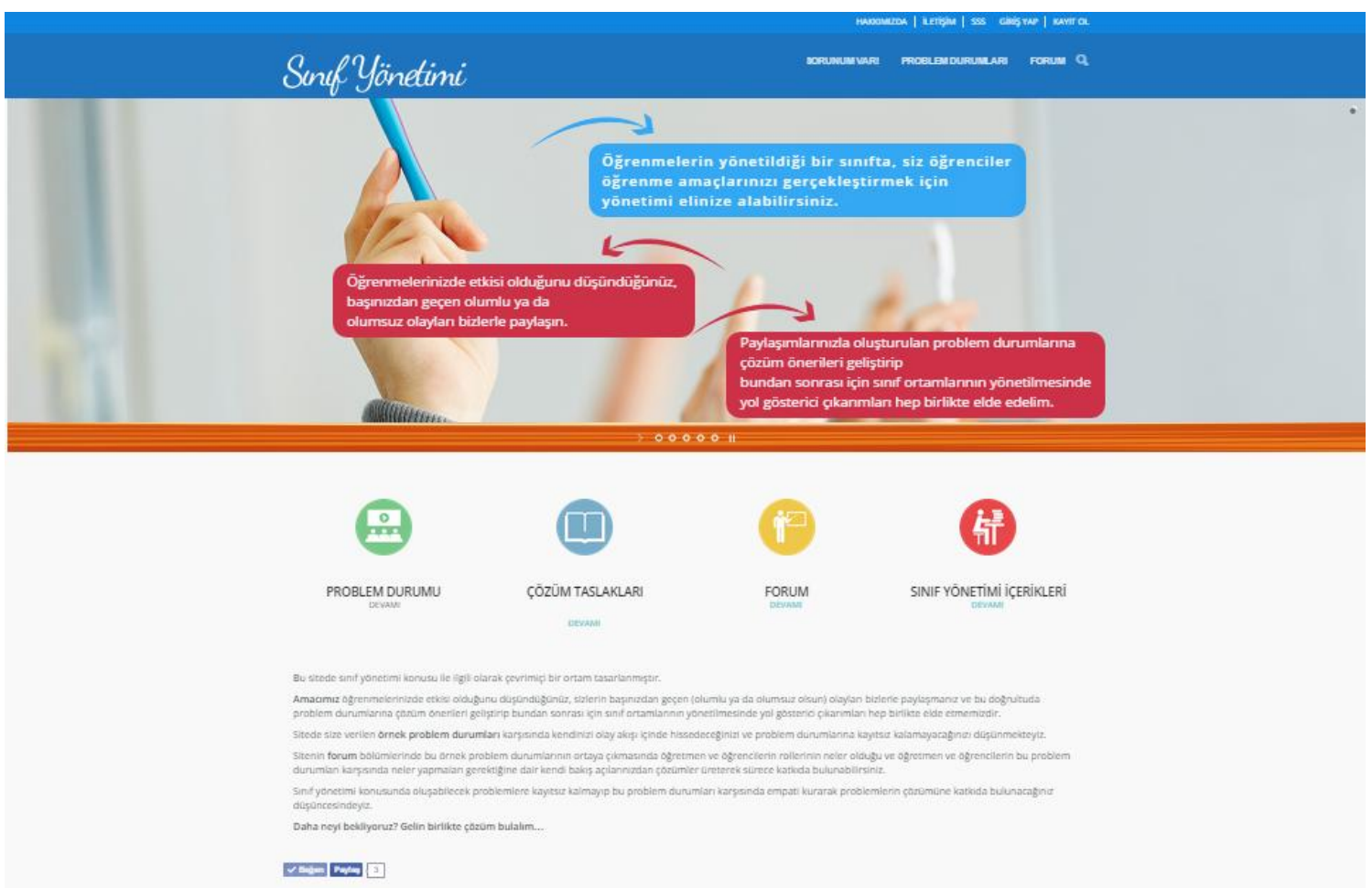

Şekil 1. Anasayfa ekran görüntüsü

Araştırmadaki gerçeği yansıtan problem durumları, çok boyutlu tartışmaya açık bir şekilde hazırlanmış olduğu ve farklı bakış açılarına göre çözümler değişebildiği için yansıtıcı düşünmeyi gerektirmektedir. Pilot uygulamada, öğretmen adaylarının meslek hayatlarında karş1laşabilecekleri bir örnek olayı konu edinen problem durumunda sorunlu bir öğrencinin okulda çıkardığı problemler sunulmuş ve devamında öğretmenin öğrenciye sorumluluk vermesiyle problem durumu bitirilmiştir. Ardından öğrencilere olay hakkında çok yönlü düşündürecek sorular yöneltilmiştir. Bu sorular, olaya öğrenci, öğretmen ve diğger koşulları da göz önüne alarak öğrencilerin kendi fikirlerini oluşturmalarını sağlayacak yönlendirici niteliktedir. Problem durumu 1'e ve yönlendirici sorulara ait bir örnek şekil 2'de verilmiştir. Ayrıca tartışmalar esnasında da araştırmacılar, verilen problem durumlarının öğrenciler tarafından farklı açılardan yorumlanmasını teşvik edecek şekilde öğrencilerin yansıtıcı düşünmelerini sağlayacak yönlendirmeler yapmışlardır. 


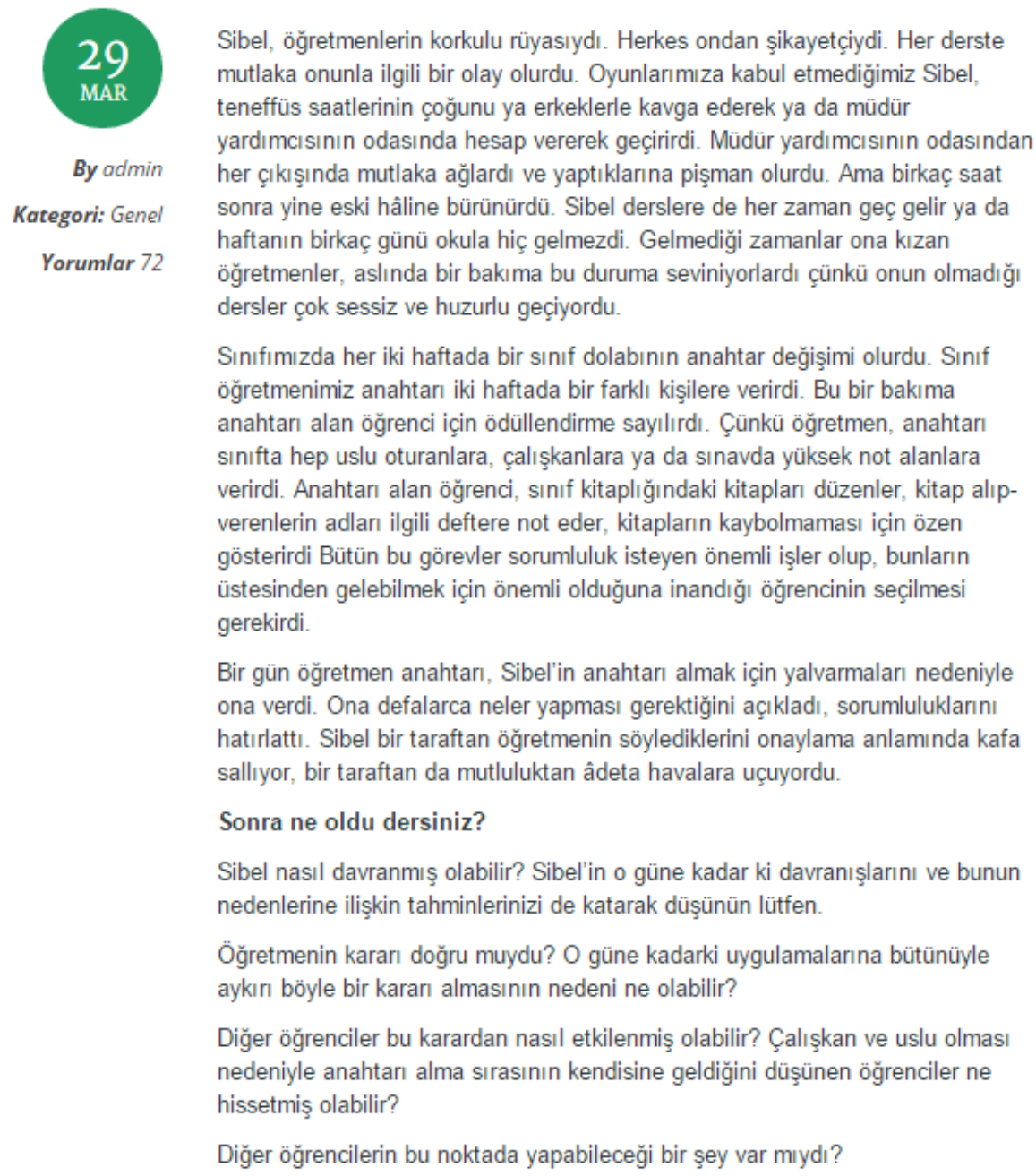

Şekil 2. Pilot uygulama problem durumu 1 ekran görüntüsü

Pilot uygulama sürecinde katılımcılara eğitimlerinde karşılarına çıkması muhtemel örnek problem durumları verilmiş ve katılımcıların verilen bu problem durumlarına çözüm önerileri getirmeleri istenmiştir. Katılımcıların pilot uygulamanın başında problem durumu 1'e verdikleri yanıtlar öntest, uygulama süreci sonunda verdikleri yanıtlar ise sontest puanları olarak değerlendirilmiştir. Süreç başında ve sonunda verilen aynı örnek olayla katılımcıların yansıtıcı düşünebilme becerilerinde bir gelişme olup olmadığı incelenmiştir.

Katılımcılar problem durumu 2'deki örnek olayı okuduktan sonra örnek olaya ilişkin düşüncelerini dile getirmişlerdir. Katılımcılar düşüncelerini çevrimiçi ortamın forum kısmına yazmışlardır. Pilot uygulama süreci esnasında araştırmacılar kolaylaştırıcı rolünde kalmış, forum sitesine yazdıkları yönlendirici sorular ile öğrencileri yansıtıcı düşünmeye teşvik 
etmişlerdir. Yönlendirici sorulara ilişkin detaylı açıklama ve örneklere nihai tasarım ve uygulama kısmında yer verilmiştir.

Problem durumu 2 için forum sayfasında yapılan tartışmalar ile katılımcıların yansıtıcı düşünebilme becerilerinin artırılması amaçlanmıştır. Ayrıca, uygulama süreci sonunda katılımcılardan geliştirilen çevrimiçi ortama yönelik görüşleri alınmıştır. $\mathrm{Bu}$ görüşler ve uygulama sürecinde karşılaşılan sorunlar dikkate alınarak çevrimiçi ortamda birtakım düzenlemeler yapılmıştır.

Anasayfada kullanılan animasyonlu geçiş sisteminde çevrimiçi ortamın amacına ve yansıtıcı düşünmeye dair daha fazla bilgi verilmesi gerektiği ve bu görselin boyutunun anasayfadaki diğer menülerin okunmasını engellediği ifade edildiği için, nihai uygulama öncesinde çevrimiçi ortamda anasayfaya daha fazla açıklayıcı bilgiler eklenmiş ve görselin boyutu diğer menülerin okunabilirliğini engellemeyecek şekilde küçültülmüştür. Çevrimiçi ortama sosyal ağ bağlantısı yapılmış ve sosyal ağda problem durumlarına yönelik ilgi çekici paylaşımlarda bulunulmuştur. Çevrimiçi ortamın renk uyumuyla ilgili belirtilen rahatsızlıklardan dolayı araştırmacılar tarafından görsel tasarıma dikkat edilmiş ve ortamdaki renk uyumu sağlanmıştır. Eski temada karşılaşılan teknik sorunlar nedeniyle aynı web sitesi adresine Wordpress'in "ParkCollage" teması kurulmuş ve çevrimiçi ortam katılımcı görüşlerine göre aynı içerikle bu temaya aktarılmıştır.

\section{Nihai Tasarım ve Uygulama}

Ortamın son şekline ilişkin ekran görüntüsü şekil 3'te verilmiştir. 


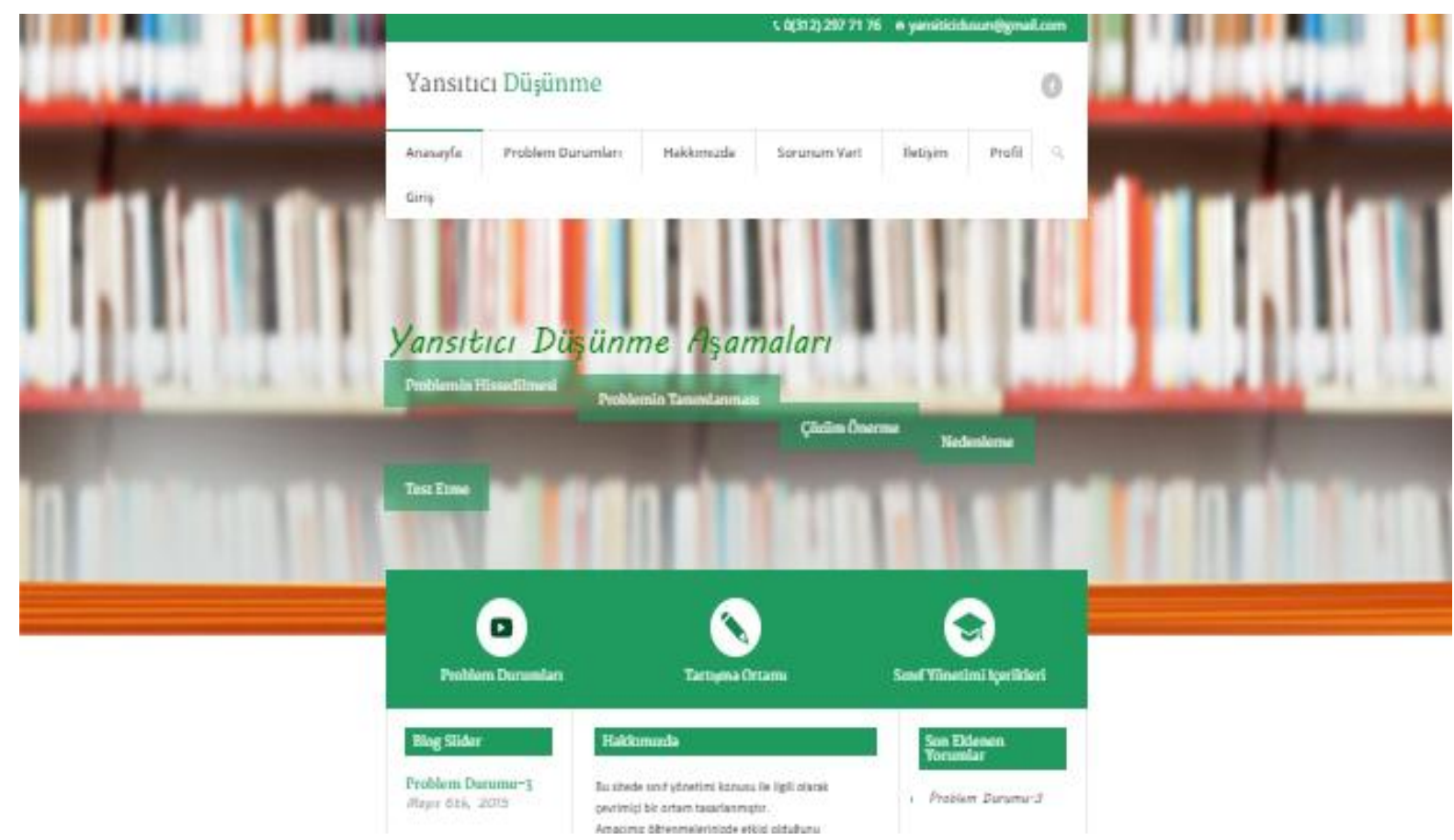

Şekil 3. Anasayfa ekran görüntüsü

Dört hafta süren nihai uygulamanın ön test ile başlayan uygulama sürecinde üç problem durumu araştırmacılar tarafından ardışık olarak tartışmaya açılmıştır. Ön test ve son test olarak kullanılan probleme verilen cevaplar, çözüm taslakları modülünde tutulmuş ve diğer öğrencilerin görüş ve tartışmasına açılmamıştır. Diğer problemler forum ortamında sunulmuş ve tartışılmıştır. Problem durumlarına ilişkin bir örnek aşağıda verilmiştir. Örnek problem durumu (ön test - son test):

“Bir çözüm yok muydu, bizim gücümüz mü sinırllydl, sorun hocaların sorunu muydu? Üniversitede dördüncü sinıf öğrencisiydim. Ĕ̈itim hayatımız projelerden, sinavlardan, staj çalışmalarından dolayı oldukça yoğundu. Bu yoğunluğa ek olarak bir de KPSS için katıldığımız kurslar vardı. Stres altındaydık ve tahammül sınırlarımız çok daralmıştı. Bu koşullar içinde en can sıkıcı olansa sevgili arkadaşımız Hakan'ın davranışlarıydl. Derslerde mutlaka bir olay çıkarıyor ve bizlerle ya da hocalarımızla sürekli kavga ediyordu. Dersin ortasında sürekli yoğunluğundan şikayet ediyor, söyleniyor, ders konularına veya verilen ödevlere itiraz ediyordu. Genelde derste en arkaya oturuyor, en ufak bir şeyden kavga çıkarıyor ve hocalarımızın yanında dahi birimize bağırıyor, sonra da kapıyı çarparak dersten çıkıyordu. Zaten yoğun olan ve stresi kendisine yeten bizler bir de onun şikayetlerini ve kavgalarını dinleyip iyice rahatsı oluyorduk. Derslerimiz verimsiz geçiyor ve eğitim hayatımı sıkıntıya giriyordu. Tam dersi dinlerken bir anda onun şikayetleri ile ders bölünüyordu. Bütün bu durumlar sadece bir ders için geçerli değildi. Hakan nedenini anlayamadĭ̆ımız bir şekilde Mehmet hocamızın derslerinde bu davranışlarının hiç birini göstermiyor, hatta dersi pür 
dikkat dinliyordu. Bir gün ders sırasında Hakan bir arkadaşımıza ufak bir şeyden dolayı bağırmaya başladı ve en sonunda kapıyı çarpıp çıktı. Hocamı ve bizler arkasından bakakalmıştık. Bu kadar sinirlenmesinin ve büyütmesinin sebebini anlayamamıştık. Hocamız arkadaşımın neden böyle davrandığını bize sordu, biz de bilmediğimizi söyledik. Ve bunun hakkında konuşmaya başladık. İşte o an fark ettim ki, ben arkadaşımın neden böyle davrandığını hiç düşünmemiştim. Benim gibi diğer arkadaşlarım da... Olaya farklı bir açıdan bakmayı düşündüm. Benim de arkadaşlarımın da aynı dersleri, aynı kursu ya da aynı stajı vardı, hepimiz yoğun ve stresliydik ama hiçbirimiz onun gibi davranmiyorduk. Onu böyle şikayetçi ve huysuz davranmaya iten sebep neydi? Ayrica hiçbirimiz Hakan'in davranışlarından bunca rahatsız olduğumuz ve derslerimizin verimsiz geçtiğinden yakındiğımız halde herhangi bir çözüm üretmeye yönelmemiştik. Bir çözüm yok muydu, bizim gücümüz mü sinırlyyd, sorun hocaların sorunu muydu?"”

Her problem durumunun ardından yansıtıcı düşünmeyi tetikleyen yönlendirici sorular eklenmiştir. Yönlendirici sorulardan örnekler aşağıdaki gibidir:

- Sizce sonrasinda neler olmuştur?

- Bu olayda sizleri rahatsiz eden durum-problem nedir?

- Belirlediğiniz problemin neden kaynaklandığını açıklayabilir misiniz? Bu soru için Kenan, arkadaşları ve asistan açısından bakarak cevap veriniz.

- Peki, bu problemin çözümü için ne gibi yollar üretebilirsiniz?

- Sonuç olarak, tartışma sürecinizden sonra doğruluğuna inandığınız çözümü paylaşabilir misiniz?

Tartışma esnasında tartışmanın verimli geçmesi ve tartışmanın amacından sapmaması için araştırmacılar tarafından kolaylaştırıcı rolünde yönlendirmeler yapılmıştır. Her bir problem durumunun tartışılması için bir hafta süre tanınarak son test ve uygulamaya yönelik görüş anketi ile nihai uygulama sonlandırılmıştır. Nihai uygulama süresi toplamda altı hafta sürmüştür.

\section{Veri Toplama Araçları}

Çalışmada öğrencilerin yansıtıcı düşünme becerilerinin gelişip gelişmediği belirlenmeye çalışılırken öğrencilerin problem durumu 1'e yönelik verdikleri öntest-sontest cevaplarının elde edilmesinde e-posta bildirim paneli kullanılmıştır. Öğrenciler bu panel vasıtası ile ad ve soyadlarını yazarak problemin çözümüne ilişkin görüşlerini araştırmacılara e-posta olarak 
göndermişlerdir. Gerek pilot uygulama sürecinde gerekse de nihai uygulama sürecinde öğrencilerin öntest-sontest cevapları Bain, Ballantyne, Mills ve Lester (2002) tarafindan dereceli puanlama anahtarı şeklinde geliştirilen beş aşamalı yansıtma düzeyleri ölçeğine göre puanlanmıştır. Öğrencilerin problem durumlarına verdikleri cevapların puanlanmasına ilişkin örnekler aşağıda sunulmuştur. Tablo 1'de araştırmada kullanılan ölçek ve ölçeğin puanlama kriterleri gösterilmiştir. Daha sonrasında ise öğrenci cevaplarına ilişkin puanlamaların nasıl yapıldığına dair örnekler verilmiştir.

Tablo 1

Araştırmada Kullanılan Beş Aşamalı Yansıtma Düzeyleri Ölçeği ve Puanlama Kriterleri

\begin{tabular}{|c|c|}
\hline $\begin{array}{l}\text { Raporlama } \\
\text { (Reporting) } \\
1 \text { puan }\end{array}$ & $\begin{array}{l}\text { - Öğrenci, gözlemlerini ekleme ve yorum katmadan düşük düzeyde } \\
\text { dönüştürme yaparak betimler, raporlar veya tekrar anlatır. }\end{array}$ \\
\hline $\begin{array}{l}\text { Yanitlama } \\
\text { (Responding) } \\
2 \text { puan }\end{array}$ & $\begin{array}{l}\text { - Öğrenci verileri düşük düzeyde dönüştürme ve kavramsallaştırma ile } \\
\text { kullanır. } \\
\text { - Öğrenci geleceğe yönelik bir çıkarsama yapmadan ve kararını nedensel } \\
\text { olarak detaylandırmadan gözlem yapar veya karar verir. } \\
\text { - Öğrenci alternatifleri düşünmeden veya cevaba yönelmeden 'rhetorical' } \\
\text { soru sorar. } \\
\text { - Öğrenci sıkıntı, endişe ve mutluluk gibi duygularını-hislerini de rapora } \\
\text { ekler. }\end{array}$ \\
\hline $\begin{array}{l}\text { İlişkilendirme } \\
\text { (Relating) } \\
3 \text { puan }\end{array}$ & $\begin{array}{l}\text { - Öğrenci verinin farklı boyutlarını, kişisel anlamları veya geçmiş ya da } \\
\text { ş̧imdiki deneyimleri ile ilişkilendirerek tanımlar. } \\
\text { - Öğrenci ilişkilerin yüzeysel anlamlarını araştırır. } \\
\text { - Öğrenci bir alandaki yaşam pratiklerinden öğrendiğini ya da bazı şeylerde } \\
\text { iyi olduğunu bazı şeyleri geliştirilmeye ihtiyacı olduğunu ya da hatalı } \\
\text { olduğunu belirtir. } \\
\text { - Bir olayın nedenini yüzeysel olarak tanımlar veya ihtiyacı olanları yapmayı } \\
\text { ya da değiştirmeyi planladıklarını betimler. }\end{array}$ \\
\hline $\begin{array}{l}\text { Nedenleme } \\
\text { (Reasoning) } \\
4 \text { puan }\end{array}$ & $\begin{array}{l}\text { - Öğrenci veriyi uygun ilişkilerde entegre eder; örn: yüksek düzey } \\
\text { dönüştürme ve kavramsallaştırma, teorik kavramlar, kişisel deneyimler ile. } \\
\text { - Öğrenci bir şeyin neden olduğuna dair derin anlamı arar. } \\
\text { - Öğrenci bir kavramı, olayı veya deneyimi inceler veya analiz eder. Bu } \\
\text { süreçte sorular sorar ve cevaplarını arar, alternatifleri göz önünde } \\
\text { bulundurur, bir şeyin neden olduğuna dair hipotez kurar veya } \\
\text { spekülasyonda bulunur. } \\
\text { - Öğrenci kendi veya diğer kişilerin davranışlarını ya da duygularını, derin } \\
\text { bir kavrayışla kendi öngörü, çıkarım, deneyim veya önceki öğrenmelerini } \\
\text { kullanarak açıklamaya yönelir. } \\
\text { - Öğrenci teori ve uygulama arasındaki ilişkiyi derinlemesine inceler } \\
\text { (keşfeder). }\end{array}$ \\
\hline $\begin{array}{l}\text { Yeniden } \\
\text { yapılandırma } \\
\text { (Reconstructing) } \\
5 \text { puan }\end{array}$ & $\begin{array}{l}\text { - Öğrenci öğrenmeyi uygularken ve/veya genelleme yaparken yüksek } \\
\text { düzeyde soyut düşünce sergiler. }\end{array}$ \\
\hline
\end{tabular}


- Öğrenci kendi yansıtmalarından orijinal bir sonuç çıkarır, kendi deneyimlerini geneller, genel ilkeler çıkarır, öğretime dair kişisel teorisini oluşturur veya öğretimsel sorunlara karşı pozisyon alır.

- Öğrenci kendi öğrenmesine yönelik kişisel anlamlarını çıkarır ve özümser ve/veya kendi yansıtmaları üzerine ileriki öğrenmelerini planlar.

Öğrenci cevaplarının puanlanmasına ilişkin örnekler:

“Evet genel olarak.”(Ö20)

Son testteki problem durumunun ardından sorulan "Bir çözüm yok muydu, bizim gücümüz mü sinırlyydl, sorun hocaların sorunu muydu? " sorusuna yukarıdaki cevabı veren Ö20'nin cevab1, açıklama içermediği için en düşük yansıtma düzeyi olan raporlama düzeyinde değerlendirilmiş ve bir puan verilmiştir.

"Hakan da diğer arkadaşları gibi zorlu bir dönemden geçiyor. Fakat ĕgitimde bireysel farklılık laf olduğu icin Hakan bu dönemlerden farklı geçirebilir. Ayrıca Hakanın baska problemleri de olabilir. Bizler ögretmenler olarak ögrencilerimizi tanımak onlarin sorunlariyla ilgilenmek zorundayı." (Ö26)

Son testteki problem durumuna yukarıdaki cevabı veren Ö26'nın cevabı incelendiğinde; Hakan'ın davranışlarının altında yatan nedeni yüzeysel olarak tanımlaması ve sonrasında bu sorunun giderilmesine yönelik yine yüzeysel bir çözüm önerisi sunmuştur. Bu doğrultuda verilen cevap ilişkilendirme düzeyinde değerlendirilmiş ve üç puan verilmiştir.

"Sorun herkesin sorunu olmallydl, ögretmen ve öğrenciler bir bütün şeklinde olmall, aslında bu sorun karşısında öğrenciler de ögretmenler de bu problemi çözme yoluna gidebilirdi. Ama maalesef ki kimse tasin altina elini koymamis. Hakan belki de psikolojik sorunlar yasiyordu belki de bu yoğunluk onu asabi biri yapmistir ama hocalardan veya Hakan in cevresinden biri Hakan la konusmus olsaydi belki Hakan düzelecekti. Konu ne olursa olsun gucumuz sinırl degil aslinda oyle yansitmak kolayimiza geliyor, sonuc itibariyle Hakan bir insan konusarak bu problem düzeltilebilirdi. Hakan in neden boyle davrandigini dusunen olmamisti. Mehmet hocanin dersinde bir kez daha boyle davranmasaydl; siniftakiler belki de Hakan neden boyle yapiyor diye dusunmeyecekti bundan bile anlasiliyor ki aslinda insanlari suclamak daha kolay insanimiz için.” (Ö6)

Yine aynı problem durumuna yukarıdaki cevabı veren Ö6'nın cevabında, Hakan'ın davranışlarının sebebini detaylı bir şekilde incelemiş, olaya tek taraflı bakmak yerine alternatifleri de göz bulundurmuş ve yansıtıcı bir süreç sonrasında bu cevabı oluşturmuştur. Bu sebeplere dayanarak Ö6'nın cevabı nedenleme düzeyinde değerlendirilmiş ve dört puan verilmiştir. 
Geliştirilen çevrimiçi ortama yönelik öğrenci görüşlerini alabilmek amacıyla öğrencilere çevrimiçi bir anket uygulanmıştır. Öğrencilere uygulatılan bu çevrimiçi anket soruları aşağıda listelenmiştir:

1) Ortam çok yönlü tartışmanızı sağlayıcı özellikler taşıyor mu? Lütfen birkaç cümleyle açıklayınız.

2) Ortamda yer alan problemler araştırma yapmanıza ve kendi fikirlerinizi sorgulamanıza yol açtı mı? Lütfen açıklayınız.

3) Ortamın görsel tasarımı hakkındaki görüşleriniz nelerdir?

4) Ortam tasarımı motive edici özellikler taşıyor mu?

5) Bu ortam çevrimiçi bir öğrenme ortamında olması beklenen özellikleri taşıyor mu?

6) Ortamda düzeltilmesi gerektiğini düşündüğünüz yerler var mı? Varsa önerileriniz nelerdir?

7) Yukarıdakiler dışında, ortam ile ilgili eklemek istediğiniz diğer hususları lütfen buraya yazınız. Görüş ve önerileriniz bizim için değerlidir.

\section{Verilerin Analizi}

Çalışmanın nicel bulguları analiz edilirken katılımcıların uygulama öncesi ve sonrasında geliştirilen çevrimiçi ortama yönelik yansıtıcı düşünme becerilerinin gelişip gelişmediği belirlenmeye çalışılmıştır. Öğrencilerin öntest ve sontest puanları Bain ve diğerleri (2002) tarafından geliştirilen yansıtıcı düşünme ölçeği kullanılarak puanlanmıştır. Ölçeğe göre öntest ve sontest verileri puanlanırken öğrencilerin raporlama, yanıtlama, ilişkilendirme, nedenleme ve yeniden yapılandırma becerileri kriter olarak alınmıştır. Öğrencilerden toplanan veriler, üç araştırmacı tarafından ayrı ayrı puanlanmış ve ortalaması alınarak nihai puanlara ulaşılmıştır. Çalışmanın nicel verilerinin analizi yapılırken pilot uygulama sürecinde öğrenci sayısı 12 olup bu sayı 30’u geçmediği için parametrik olmayan test istatistiklerinden Wilcoxon işaretli sıralar testi kullanılmıştır. Bu test istatistiğine göre ilişkili iki ölçüm setine ait puanlar arasındaki farkın anlamlılığı test edilmiştir (Büyüköztürk, 2012). Nihai uygulama sürecinde ise öğrenci sayısı 30 olduğu için parametrik test istatistiklerinden ilişkili örneklemler t-testi kullanılmıştır. $\mathrm{Bu}$ test istatistiğine göre ilişkili iki örneklem ortalaması arasındaki farkın anlamlılığı test edilmiştir. Çevrimiçi ortama yönelik öğrenci görüşleri analiz edilirken ise içerik analizi yöntemi kullanılmıştır. 


\section{Bulgular}

Geliştirilen çevrimiçi ortamın öğrencilerin yansıtıcı düşünebilme becerilerine etkisi nicel boyutta ve geliştirilen bu çevrimiçi ortama yönelik öğrenci görüşleri ise nitel boyutta ele alınmıştır. Aşağıda oluşturulan çevrimiçi ortama yönelik pilot uygulama bulguları ile ortamda düzenlemeler yapıldıktan sonra elde edilen nihai uygulama bulguları verilmiştir.

\section{Oluşturulan Çevrimiçi Ortamın Öğrencilerin Yansıtıcı Düşünebilme Becerilerine Etkisine Yönelik Pilot Uygulama Bulguları}

Oluşturulan çevrimiçi ortamın öğrencilerin yansıtıcı düşünebilme becerilerine etkisinin belirlenmesi amacıyla öğrencilerin pilot uygulamanın başında problem durumu 1'e verdikleri yanıtlar öntest, pilot uygulama sonunda verdikleri yanıtlar ise sontest puanları olarak ele alınmıştır.

Pilot uygulama süreci boyunca problem durumu 1'e öntest ve sontest olarak veri giren öğrenci sayısı 12 olduğundan çalışmanın nicel verileri bu 12 öğrenci üzerinden analiz edilmiştir. Analiz edilen bu öğrenci verilerinin betimsel test istatistik sonuçları tablo 2 'de verilmiştir.

Tablo 2

Pilot Uygulamaya Katılan Öğrencilerin Betimsel Test İstatistik Sonuçları

\begin{tabular}{llll}
\hline & $\mathrm{n}$ & $\overline{\mathrm{x}}$ & $\mathrm{S}$ \\
\hline Öntest & 12 & 31,25 & 12,81 \\
\hline Sontest & 12 & 35 & 12,61 \\
\hline
\end{tabular}

Tablo 2 incelendiğinde öğrencilerin sontest puan ortalamalarının öntest puanlarına göre artış gösterdiği görülmektedir. Örneklem sayısı 30'dan küçük olduğu için bu artışın anlamlı olup olmadığı parametrik olmayan test istatistiklerinden Wilcoxon işaretli sıralar testi kullanılarak test edilmiştir. Tablo 3'te ilişkili ölçümler için Wilcoxon işaretli sıralar testi sonucu gösterilmiştir. 
Tablo 3

Yansitıcı Düşünebilme Öntest-Sontest Puanlarına İlişkin İlişkili Ölçümler İçin Wilcoxon İsaretli Sıralar Testi Sonuçları

\begin{tabular}{llllll}
\hline Sontest-Öntest & $\mathrm{n}$ & Sıra Ortamalası & Sıra Toplamı & $\mathrm{Z}$ & $\mathrm{p}$ \\
\hline Negatif Sıra & 0 & 0 & 0 & 2.71 & .00 \\
Pozitif Sıra & 8 & 4.5 & 36 & & \\
Eşit & 4 & & & & \\
$*$ Negatif sıralar temeline dayalı & & &
\end{tabular}

Analiz sonuçlarına göre çalışmaya katılan öğrencilerin yansıtıcı düşünme beceri öntest-sontest puanları arasında anlamlı bir fark görülmektedir, $\mathrm{z}=2.71, \mathrm{p}<.05$. Fark puanlarının sıra ortalaması ve toplamları dikkate alındığında gözlenen bu farkın pozitif sıralar, yani sontest puanları lehinde olduğu görülmektedir. Bu sonuca göre oluşturulan çevrimiçi ortamın öğrencilerin yansıtıcı düşünme becerileri üzerinde anlamlı bir etki yaratabileceğine dair ipucu elde edildiği söylenebilir.

\section{Geliştirilen Çevrimiçi Ortamın Öğrencilerin Yansıtıcı Düşünme Becerilerine Etkisine Yönelik Nihai Uygulama Bulguları}

Geliştirilen çevrimiçi ortamın nihai uygulamasının öğrencilerin yansıtıcı düşünme becerilerine etkisinin belirlenmesi amacıyla öğrencilerin nihai uygulamanın başında problem durumu 1'e verdikleri yanıtlar öntest, nihai uygulama sonunda verdikleri yanıtlar ise sontest puanları olarak ele alınmıştır.

Çalışmada nihai uygulamaya katılan öğrenci sayısı 30 olduğundan parametrik test istatistiklere gidilerek verilerin analizi için ilişkili örneklemler t-testi kullanılmıştır. Öncelikle ilişkili örneklem t-testi uygulayabilmek için gerekli sayıltıların sağlanıp sağlanmadığı test edilmiştir. Sayıltıların yerine gelmesi için bağımlı değişkene ait ölçümlerin en az aralık ölçeğinde olması ve ilişkili ölçüm setine ait fark puanlarının normal dağılım göstermesi gerekmektedir. Sayıltılar incelendiğinde bağımlı değişkene ait ölçümler en az aralık ölçeğindedir. Normalliğe uygunluğunu incelemede grup büyüklügünün 50'den küçük olması durumunda Shapiro-Wilks, büyük olması durumunda ise Kolmogorov-Smirnov (K-S) testleri kullanılmaktadır (Büyüköztürk, 2012:42). Gruplardaki örneklem sayısı 50'nin altında olduğu için analiz sonuçları Shapiro-Wilks testine göre yorumlanmıştır. Yapılan Shapiro-Wilks testine göre fark puanları .05 değerinden büyük olduğu için $(p=.07)$ veriler istatiksel olarak normal dağılım 
göstermiştir ( $\mathrm{p}>.05)$. Sayıltılar sağlandığ 1 için parametrik test istatistikleri ile analizlere devam edilmiştir. Öntest ve sontest ortalama puanları arasındaki farkın anlamlılığı için yapılan ilişkili ölçümler t-testi sonuçları tablo 4’te gösterilmiştir.

Tablo 4

Yansıtıcı Düşünebilme Öntest-Sontest Puanlarına İlişkin İlişkili Ölçümler T-Testi Sonuçları

\begin{tabular}{lllllcc}
\hline Ölçüm & $\mathrm{n}$ & $\overline{\mathrm{x}}$ & $\mathrm{S}$ & $\mathrm{sd}$ & $\mathrm{t}$ & $\mathrm{p}$ \\
\hline Öntest & 30 & 2.31 & .63 & 29 & -8.19 & .000 \\
Sontest & 30 & 3.38 & .78 & & & \\
\hline
\end{tabular}

Analiz sonuçlarına göre nihai uygulamaya katılan öğrencilerin yansıtıcı düşünme beceri öntest puan ortalamaları $\bar{x}=2.31$ iken sontest puan ortalamaları $\bar{x}=3.38$ 'e çıkmıştır. Tablo 4 incelendiğinde öntest ve sontest puanları arasında anlamlı fark görülmektedir, $t(29)=-8.19$, $\mathrm{p}<.00$. Bu sonuca göre geliştirilen çevrimiçi ortamın öğrencilerin yansıtıcı düşünme becerileri üzerinde anlamlı bir etki yarattığı söylenebilir.

\section{Geliştirilen Çevrimiçi Ortama Yönelik Nihai Uygulama Öğrenci Görüşleri}

Pilot uygulama sürecinde öğrencilere yöneltilen çevrimiçi ortama yönelik sorular nihai uygulama sürecinde de sorulmuştur ve nihai uygulamaya katılan 30 öğrencinin görüşleri analiz edilmiştir.

Çevrimiçi ortamın çok yönlü tartışmaya olanak verip vermediğine yönelik öğrenciler; problemlerin düşünmelerini sağlayıp farklı bakış açılarını görmelerini sağladığını, çevrimiçi ortamdaki problemlerin düşündürücü özellikler barındırdığını, değişik fikirler ile problemlerin her yönden ele alındığını, çevrimiçi ortamın rahat bir tartışma ortamı sağladığını, başkalarının düşüncelerini okuyarak kendi düşüncelerini eleştirme imkanı bulduklarını, çözüm odaklı öneriler yapıldığını ve tek taraflı bakılamayacak hikayeler verildiğini belirmişlerdir. Öğrencilerden bazıları ise çevrimiçi ortamda tepkisiz ve önyargılı yorumlar yapıldı̆̆ını, öğrencilerin sorunlar arasında sıkılıp birbirlerini dinlemediğini, çevrimiçi ortamın yoğun ve stresli olduğunu ayrıca yorumların tam olarak bilinçli şekilde yapılmadığını ifade ederek çevrimiçi ortamın çok yönlü tartışmaya olanak vermediğini vurgulamışlardır. Bu doğrultudaki bazı öğrenci görüşleri aşağıda verilmiştir. 
"Evet çünkü problemler düşünmemizi sağllyor. Aynı zamanda yapılan yorumlarda farklı boyuttaki bakış açılarını görmemize yardımcı oluyor. ” (Ö6)

"Ortamda değişik fikirlerle problemlerle karşılaşmak konuyu her yönden ele almamı să̆llyor." (Ö8)

"Evet. Başkalarının da düşüncelerini görme ihtimalimiz olduğu için kendi düşüncelerimizi de içsel olarak eleştirerek farklı bakış açıları kazanabiliyoruz." (Ö13)

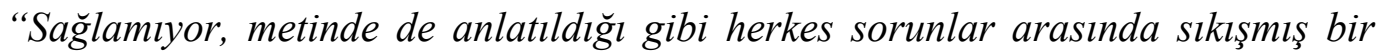
vaziyette kimsenin kimseyi dinleyecek hali yok.” (Ö4)

"Ortamın yoğun ve stresli olması çok yönlü tartışma olanağını elden çıkarmaktadır." (Ö16)

Çevrimiçi ortamda yer alan problemlerin öğrencilerin kendi fikirlerini sorgulayıp sorgulamadığına yönelik öğrenciler; fikirlerini sorgulayarak doğruyu bulmaya çalıştıklarını, kendilerinin de belirtilen problem durumlarına benzer problemler yaşayıp şahit olduklarını, bazı konular hakkında araştırma yaptıklarını, öğretmen olduklarında karşılaşabilecekleri problemlere nasıl yaklaşabileceklerini düşündüklerini, bulunulan ortamda neden böyle davranışlar sergilendiğini düşünüp çözüm yolları aramaya başladıklarını, farklı düşünceler ile kendi fikirlerini sorgulayabildiklerini, ortamdaki problem durumlarının fikirlerinin olgunlaşmasına zemin hazırladığını, ortamın kendi fikirlerini ele alıp yeniden düşünmelerini sağladığını, problem durumlarını okuduklarında çok konuşan öğrencileri sevebileceklerini inandıklarını, bilmedikleri konuları araştırma firsatı bulduklarını ve kendilerini araştırmaya sevk ettiğini dile getirmişlerdir. Bu ifadelere yönelik öğrenci görüşlerinden bazıları şu şekildedir:

“Evet sorgulayarak doğruyu bulmaya çalıştım.” (Ö1)

"Evet bazı konular hakkında araştırmalar yaptım (sınıf yönetimi, otistik çocuklar hakkında mesela).” (Ö5)

"Evet. Problemlere karşı nasıl davranırım diye internetten bilgi aldım ve bu bilgileri kendi düşüncelerimle birleştirdim.” (Ö8)

"Kesinlikle. Ben şuanda bile düşünmeye başladım ortamın etkisini. Bulunulan ortamda neden böyle davranışlar sergilendi gibi soruların cevabını aramaya başladım." (Ö11)

"Problemler sayesinde neler yapmalıyz ya da neler yapmamallyı gibi fikirlerimizi araştırmaya yöneltip sorgulamamızı sağladı. Çoğu zaman kendi fikirlerimizi ele alıp yeniden düşünmemizi sağladı." (Ö17) 
Çevrimiçi ortamın görsel tasarımına yönelik öğrenciler; ortamın görsel tasarımını beğendiklerini, görselliğin olması gerektiği gibi güzel tasarlandığını, tasarımın sade ve güzel olduğunu, görselliğin yönlendirici özellikler barındırdığını, merak uyandırıcı olduğunu ayrıca rahatlatıcı ve iç açıcı olduğunu belirtmişlerdir. Bunun yanında bazı öğrenciler görsel tasarımın yetersiz olduğunu ve tasarımı daha ilgi çekebilecek hale getirecek tarzda görsellerin çevrimiçi ortama eklenmesi gerektiği düşüncelerini dile getirmişlerdir. Çevrimiçi ortamın görsel tasarımına yönelik öğrenci görüşlerinden bazıları aşağıda belirtilmiştir.

"Ortamın görsel tasarımı olması gerektiği gibi gereksiz herhangi bir şey göremiyorum." (Ö7)

“Ortamın görsel tasarımı oldukça güzel ve yönlendiricidir.” (Ö17)

"Görsel tasarım başarılı ve insanın dikkatini çekeceği bir şekilde hazırlanmış. Çok güzel. Yeşil renk seçimi uygun olmuş.” (Ö23)

“Görsellerin daha çok dikkat toplaması ve motive edici olması lazım” (Ö19)

“Görsel tasarımı yetersiz buldum.”(Ö25)

Çevrimiçi ortamın motive edici özellikle taşıyıp taşımadığına yönelik öğrencilerin büyük bir bölümü ortamın motive edici özellikler taşıdığını, diğer öğrenciler ise ortamda motive edici özelliklere rastlamadıklarını vurgulamışlardır. Bu doğrultudaki bazı öğrenci görüşleri aşağıda verilmiştir.

“Evet motive edici özellik taşıyordu.” (Ö20)

“Evet gayet motive edici özellikteydi." (Ö5)

“Motive edici etmek bir yana daha dursun, insanı kasan bir ortam var.” (Ö26)

“Böyle sorunların motive edici olduğunu kesinlikle düşünmüyorum. Aksine kişinin moralini bozarak ortam dışında bile bu ortamın bıraktığ olumsuz etkiyi yaşatıyor." (Ö30)

Geliştirilen ortamın çevrimiçi bir öğrenme ortamında olması beklenen özellikleri taşıyıp taşımadığına yönelik öğrencilerin bir bölümü ortamın çevrimiçi ortamda olması gereken özellikleri barındırdığını diğer bölümü ise barındırmadığını veya yapılabilecek birtakım düzenlemeler ile ortamın tam olarak çevrimiçi bir hale gelebileceğini dile getirmişlerdir. $\mathrm{Bu}$ açıklamalara yönelik bazı öğrenci görüşleri ise şu şekildedir. 
"Biraz daha aktiflik sağlansa kesinlikle çevrimiçi bir ortam özelliklerini taşır." (Ö5)

“Bu ortamda tek sorun [çevrimiçi ortam] biraz daha aktif edilebilirdi.” (Ö20)

“Klsmen taşıyor ama daha güzel bir ortam yapılabilir.” (Ö25)

“Tam anlamı ile değil dönütler azdı.” (Ö28)

"Çevrimiçi bir eğitim ortam özelliklerini taşıyordu biraz daha özen gerekiyordu (dönütler ve geçen süreler gibi).” (Ö29)

Çevrimiçi ortamda geliştirilmesi gereken yerler olup olmadığına dair öğrenciler; ortamda öğrencilere yüklenen sorumlulukların fazla olduğunu ve bu sorumlulukların azaltılması gerektiğini, siteye daha çok yol gösterici özelliklerin eklenmesi gerektiğini, problem davranışlarına yol açan durumlardan bahsedilmesi gerektiğini, ortamın katılımcıların birbirine daha saygılı olabilecekleri şekilde düzenlenebileceğini, tartışmaya daha açık konular eklenebileceğini, ortama rahatlatıcı tarzda müzikler eklenebileceğini, site yöneticilerinin uygulamalar esnasında katılımcılara daha fazla dönüt ve ortama yön vermesi gerektiğini ifade etmişlerdir. Bu görüşlerin yanında diğer öğrenciler çevrimiçi ortamda geliştirilmesi gereken bir özellik olmadığını dile getirmişlerdir. Bu ifadeleri destekleyen bazı öğrenci görüşleri aşağıda verilmiştir.

"Site daha kllavuz niteliğinde olabilir. Net olmayan ifadelerin yanina parantez içerisinde açıklama yapılabilir." (Ö4)

"Ortam paylaşıma daha açı ve insanların birbirine saygl duyacakları şekilde düzenlenmelidir. Bu ortamda gayet başarılı düzenlenmiştir." (Ö23)

"Daha motive edici hale getirilebilir. Bu da rahatlatıcı bir müzik olur, duvar boyaların rengi olabilir." (Ö26)

"Ortamda serilik ve adminlerin daha dönüt vermesi gerekiyordu bunun düzeltilmesi lazım.” (Ö27)

“Bence ortam gayet zarif. Sınıf ortamını andırlyor. Olduğu gibi kalsın.” (Ö17)

Öğrenciler geliştirilen çevrimiçi ortamın geliştirilmesine yönelik ek olarak; site yöneticilerinin daha fazla dönüt vermeleri gerektiği, problem durumlarının artırılıp ortamın daha ilgi çekici hale getirilebileceği ve arada fazla süre bırakmadan yeni problem durumlarının eklenip açıklamalar yapılması gerektiği yönünde düşüncelerini dile getirmişlerdir. Öğrencilerin büyük 
çoğunluğu ise geliştirilen çevrimiçi ortamı yeterli bulmuşlardır. Dile getirilen bu önerilerden bazıları aşağıda belirtilmiştir.

"Ortamla ilgili eklemek istediğim şey yöneticilerin daha fazla yorumlar yazıp dönüt vermesi ve problem durumlarını daha fazla artırıp ortamı daha da ilgi çekici durumuna getirmesi..."(Ö5)

"Ortam ögrenme ve ögretme bakımından çok yararlıdır. Her zaman bu gibi ortamların olması ve gerek eleştirel gerek sorgulayıcı şekilde tartışma sağlayan durumların olmasl gereklidir." (Ö17)

"Güzel bir öğrenme ortamı olmuş gerek yöneticilerle, gerekse problem sayısını çoğaltıp ortamı hareketlendirmeniz güzel olur.” (Ö20)

"Arada bu kadar uzun sure geçmeden yeni problemler açılabilirdi. Kesinlikle daha fazla dönüte ve bilgilendirilmeye ihtiyaç vardl.” (Ö29)

Çalışmanın nicel ve nitel bulguları genel olarak yorumlandığında; geliştirilen çevrimiçi ortamın öğrencilerin yansitıcı düşünebilme becerilerine ve öğrencilerin çok yönlü düşünüp düşüncelerini yansıtıcı şekilde ifade edebilmelerine olumlu katkılar sağlayabileceği, öğrencilerin kendi fikirlerini sorgulamalarına imkan verebildiği, genel olarak bir çevrimiçi ortamdan beklenen özellikleri taşıdığı ve bu çevrimiçi ortamda yapılabilecek bir takım düzenlemeler ile ortamın daha verimli olabileceği söylenebilir.

\section{Geçerlik ve Güvenirlik Önlemleri}

Erlandson, Harris, Skipper ve Allen'a (1993) göre nitel çalışmaların inandırıcılığını artırabilmek için veri kaynakları ile uzun süreli etkileşim, derin odaklı veri toplama, veri çeşitlemesi, uzman incelemesi ve katılımcı teyidi; aktarılabilirlik için ise ayrıntılı betimleme ve amaçlı örnekleme gibi yöntemler kullanılmaktadır. Bu çalışmanın iç geçerliğini bir diğer ifade ile inandırıcılığını sağlayabilmek için ham veriler ve analizler uzmanlar tarafindan incelenerek geribildirimler verilmiştir. Katılımcılar ile uzun süre etkileşim içerisinde olunarak zaman içerisinde güven ortamı oluşturulmuştur. Böylece katılımcılar kendilerine yöneltilen sorulara daha samimi yanıtlar vermiştir. Ayrıca çalışmaya katılımcıların gönüllü olarak katıldıklarına dair katılımı teyidi alınmıştır. Araştırmanın dış geçerliğini veya aktarılabilirliğini sağlamak adına bulgular doğrudan alıntılarla tanımlanmış ve veriler ayrıntılı bir şekilde raporlaştırılmıştır. İç güvenirliği yani tutarlılığı sağlamak adına araştırmacılar, 
doğrudan alıntılama yapılan öğrenci görüşlerinin belirtilmesi esnasında kendi yorumlarını verilere katmamıştır. Dış güvenirliğin yani teyit edilebilirliği sağlamak adına ise katılımcılara ortam ve süreç hakkında tanıtımlar yapılmıştır.

\section{Sonuç, Tartışma ve Öneriler}

$\mathrm{Bu}$ çalışma yansıtıcı düşünme becerilerini harekete geçirecek, becerilerin kullanılmasını ve geliştirilmesini sağlayacak bir çevrimiçi ortam oluşturmak ve bu ortamın yansitıcı düşünme becerilerinin gelişimi açısından etkililiğini incelemek üzere gerçekleştirilmiştir. $\mathrm{Bu}$ amaçla çalışmada öğrencilerin yansıtıcı düşünme becerilerinin gelişmesine yönelik çevrimiçi bir ortam tasarlanmıştır. Tasarım, geliştirme, pilot uygulama, yeniden geliştirme, nihai uygulama ve değerlendirme aşamalarından oluşan sürecin ardından öğrencilerin yansitıcı düşünme becerilerinin gelişimi ve ortamın niteliğine ilişkin görüşleri incelenmiştir.

Ortamdaki tartışmaların ölçek kullanılarak puanlanması yoluyla elde edilen verilere göre öğrencilerin yansıtıcı düşünme becerilerinde anlamlı bir iyileşme gözlenmiştir. $\mathrm{Bu}$ sonuç, etkileşimli çevrimiçi tartışma ortamlarının yansıtıcı düşünmeyi geliştireceği yönündeki görüşleri (Jorgensen, 2002; Salmon, 2002) destekleyici niteliktedir. Katılımcı bazı öğrencilerin, forum sayfasında diğer katılımcı öğrencilerin yazdıkları yorumları okumalarının kendi yansıtıcı düşünme becerileri üzerinde olumlu etkisi olduğunu ifade etmiş olmaları da dikkate değer bulunmuştur. O halde çevrimiçi ortamlar yalnızca özgür bir tartışmaya firsat sağlamaları açısından değil, aynı zamanda öğrencilere birbirlerinin görüşlerini karşılaştırmalı olarak okuma olanağı vermesi ile de yansıtıcı düşünmenin gelişimini desteklemektedir.

Öte yandan alan yazında çevrimiçi eş zamansız durum tartışmalarının öğrencilere ekstra yük getirdiği ile ilgili bazı çalışmalara da rastlanılmıştır. Lee (2008), öğrencilerin eş zamansız tartışmaların kendilerine fazladan uğraş getirdiğini düşündüklerini belirterek çevrimiçi ortamdaki birçok mesajın öğrenciler tarafindan okunmaya değer bulunmadığını ve öğrencilerin bu mesajları okumakla geçen süreyi zaman kaybı olarak nitelediklerini vurgulamıştır. $\mathrm{Bu}$ durum Jones (2000) tarafından, öğrencilerin çevrimiçi tartışmalara fazla katılmamasının, öğrencilerin mesajların yalnızca bir kısmının okumasına ya da mesajları okumadan yalnızca kendi görüşlerini yazmak için tartışmaya katılmalarına neden olduğuna bağlanmıştır. Bu görüşler öğrencilerin ortam mesajlarını katkı getirici, değerli ya da ilginç bulmadıklarının göstergesi olabilir. Bu çalışmada tersi sonuçlar alınması öğrencilerin, yansiticidusun.net adresli 
çevrimiçi ortamında paylaşılanları anlamlı buldukları yönündeki görüşümüzü desteklemektedir.

Ayrıca, öğrencilere yöneltilen problem durumlarının gerçek hayatta kendilerinin karşılaşabilecekleri muhtemel olaylar olmasının, problem durumlarında öğrencilere yöneltilen yansıtıcı düşünme sorularının ve araştırmacıların süreç içerisinde forum sayfasında öğrencileri yönlendirmeye çalışmalarının öğrencilerin yansıtıcı düşünme becerilerine olumlu katkılar sağlamış olabileceği düşünülmektedir. Çalışmada bazı öğrencilerin problemlere ilişkin değerlendirmeleri ve çözüm önerilerinin ön test ve son testte değişmediği gözlenmiştir. Bazı öğrenciler bunu kendileri de ifade etmiştir. Bu durum, çalışma süresinin kısalığı ile ilgili olabilir. Alan yazında öğrencilerin yansıtıcı düşünme becerilerinin gelişiminin zaman alan bir süreç olduğu ifade edilmektedir (Ünver, 2003). Ayrıca gözlenen sonuç, bir çevrimiçi ortamın, niteliği ne olursa olsun tüm öğrenciler için etkili olamayacağı gerçeğinin hatırlatıcısı olarak da değerlendirilebilir.

Ortamın görsel tasarımına yönelik genel görüşler ortamın görselliğinin geliştirilebilir olduğu yönündedir. Öğrencilerden bazıları çevrimiçi ortamın görsel tasarımını güzel bulmasına rağmen bazıları beğenmemişlerdir. Bu durum görsel algı kavramın göreceli bir durum olmasına ve estetik kavramının kişiden kişiye göre değiştiğinin bir göstergesi olarak ifade edilebilir. Tam bir temsil edicilik değeri taşımasa da çalışmanın pilot ve nihai uygularından elde edilen nicel ve nitel bulguların benzerlik göstermesi geliştirilen çevrimiçi ortamın, öğrencilerin yansıtıcı düşünme becerileri üzerinde olumlu katkılar sağladığının destekleyici göstergesi olarak yorumlanabilir.

$\mathrm{Bu}$ çalışmanın nihai uygulamasına birkaç üniversiteden sadece 30 gönüllü öğrenci katılım göstermiştir. Çalışmanın nihai uygulaması dört hafta ile sınırlı tutulmuştur. Çalışma ayrıca üç problem durumu üzerinden yürütülmüştür. Çevrimiçi tartışma ortamlarında öğrencilerin yansıtıcı düşünme becerilerini geliştirmeye yönelik çalışma yapmak isteyen araştırmacılar daha geniş örneklem grupları ve daha farklı problem durumları kullanarak çalışmayı tekrarlayabilir. 


\section{Kaynakça}

Arkün, S. ve Erdem, M. (2007). BİT destekli öğretmen eğitimi modelleri üzerine bir inceleme. Uluslararası Öğretmen Yetiştirme Politikaları ve Sorunları Sempozyumu Bildiriler Kitabı içinde (ss.492-496), Bakü, Azerbaycan.

Bain, J. D., Ballantyne, R., Mills, C. ve Lester, N. C. (2002). Reflecting on practice student teachers' perspectives. Flaxton, QLD: Post Pressed.

Büyüköztürk, Ş. (2012). Sosyal bilimler için veri analizi el kitabı: istatistik, araştırma deseni SPSS uygulamaları ve yorum, (16. baskı), Ankara: Pegem Yayınları.

Creswell, J. W. (2003). Research design: Qualitative, quantitative and mixed methods approaches (2. bask1), California, CA: Sage.

Dewey, J. (1991). How we think. New York, NY: Prometheus Books.

Erlandson, D. A., Harris, E. L., Skipper, B. L. ve Allen, S. T. (1993). Doing naturalistic inquiry: A guide to methods. Beverly Hills, CA: Sage.

Hew, K. ve Cheung, W. (2008) Attracting student participation in asynchronous online discussions: Case study of peer facilitation. Computers \& Education, 51, 1111-1124.

Jonassen, D. (1999). Designing constructivist learning environments. In Ed. C. M. Reigeluth (Ed.) Instructional-Design theories and models içinde (ss.215-239). London: Lawrance Erlbaum Associates Publishers.

Jones, O. (2000). Time to split, virtually: Expanding virtual publics into vibrant virtual metropolises. 33rd Hawaii International Conference on System Sciences [33. Hawaii Uluslararası Siste Bilimleri Konferansı] bildiri kitabı içinde. DOI: 10.1109/HICSS.2000.926810.

Jorgensen, D. (2002). The challange sand benefits of asynchronous learning networks. Reference Librarian, 77 (1), 3-17.

Lee, H. (2008). Students' perceptions of peer and self assessment in a highereducation online collaborative learning environment. (Yayımlanmamış doktora tezi). Texas Üniversitesi, Austin, ABD. 
Makoul, G., Zick, A. B., Aakhus, M., Neely, K. J. ve Roemer, P. E. (2010). Using an online forum to encourage reflection about difficult conversations in medicine. Patient Education and Counseling, 79 (1), 83-86.

Mettiainen, S. ve Vahamaa, K. (2013). Does reflective web-based discussion strengthen nursing students'learning experiences during clinical training? Nurse Education in Practice, 13, 344-349.

McNamara, J. ve Brown, C. (2008, Kasım). Assessment of collaborativelearning in online discussions. ATN Assessment Conference 2008 [2008 ATN Değerlendirme Konferansi]'nda sunulmuş bildiri. Güney Avusturalya Üniversitesi, Adelaide, Avusturalya.

Nicholson, S. A. ve Bond, N. (2003). Collaborative reflecion and professional community building: An analysis of preservice teachers' use of an electronic disscussion board. Journal of Technology and Teacher Education, 1(2), 147-155.

Onwuegbuzie, A. J. ve Leech, N. L. (2006). Linking research questions to mixed methods data analysis procedures. The Qualitative Report, 11(3), 474-498. http://www.nova.edu/ssss/QR/QR11-3/onwuegbuzie.pdf adresinden 20 Nisan 2013 tarihinde alınmıştır.

Özçınar, H. (2011). Video-durumlarda yansıma noktalarının ve tartışma gruplarında öğretmen katılımının yansıtıcı düşünmeye etkisi. (Yayımlanmamış Doktora Tezi). Ankara Üniversitesi, Eğitim Bilimleri Enstitüsü, Ankara.

Ramos Hernandez, P. (2004). Web logs and online discussions as tools to promote reflective practice. The Journal of Interactive Online Learning, 3(1), 1-16.

Revill, G. ve Terrell, I. (2005). Learning in the workplace: A new degree online. Innovations in Education and Teaching International, 42(3), 231-245.

Rodgers, C. (2002). Defining reflection: Another look at John Dewey and reflective thinking. Teachers College Record, 104(4), 842-866.

Rugg, H. (1947). Foundations for American education. New York, NY: World Book Company.

Salmon, G. (2002). E-tivities: The key to active online learning. London: KoganPage. 
Schön, D.A. (1983). The reflective practitioner: How professionals think in action. New York, NY: Basic Books.

Taggart, G. L. ve Wilson, A. P. (2005). Promoting reflective thinking in teachers: 50 action strategies, (2. bask1), Thousand Oaks, London, New Delhi: Sage Publications.

Ünver, G. (2003). Yansıtıcı düşünme. PegemA Yayınc1lık, Ankara. 


\section{Extended Abstract}

Reflective thinking can also be provided in both online discussing forums and classrooms. In addition to oral lectures in classes, it is aimed to structure students' self learning and to improve new learning styles with provided online discussing forums . Students learning in online discussing forums improve their reflective and critical thinking abilities by constructing their interpretation, explaining activities, developing different perspectives, comparing and thinking on these perspectives (Jorgensen, 2002). As using of online discussing forums gives time to students to analyze and evaluate their own and others' answers carefully, it encourages more reflective studying than studying alone. Moreover, online discussing forums provide an environment to improve reflective thinking for students (Salmon, 2002).

This study has been carried out to improve an online media which activates reflective thinking abilities, enables these abilities and improves them and also to analyze the effectiveness of this media. In this study, it is aimed that by giving problem situations related to classroom management, students are expected to discuss these problems in a reflective thinking way and to offer their own solutions. For this purpose, researchers have developed a website called 'yansiticidusun.net'. In this media which has been designed by using Wordpress content management system, ParkCollage theme has been used. Besides, Slider has been used at the home page to motivate students visually and to get their attention to some explanations about the media. In general terms, the home page consists of three main parts. These are Problem Situations that has examples about classroom management, Platform where students can discuss given problem situations with other users and Contents of Classroom Management where they can find input data of models about classroom management. Other menus are About Us, Contacts and Frequently Asked Questions. Furthermore, to create problem situations in the online media, there is a menu called I Have A Question where they can share their problems and views about classroom management.

The problems used in the media are the real classroom problems that students may also encounter in their future career and that have more than one answer. After each question, some questions which enable thinking reflectively have been asked to the participants. The researchers have played a facilitator role while the problem situations that were started after 
pre-test have being discussed. Routing has been made to the participants to lead the discussion into the right direction which doesn't include any information.

The environment taken from class management has been examined on a group of university students and the students' thoughts related to the quality of the environment have been got. Mixed design has been used in the study. While investigating the effect of the online environment on the students' reflective thinking skills, quantitative; while getting the students' opinions related to the environment, qualitative data was used. To determine the effect of the environment on reflective thinking skills, a class management problem has been given the students and analyses have been required. The differences in the analysis have been evaluated with Manouchehri (2002) reflective thinking scale giving the same problem at the beginning and end of the process. The consequences used as pretest-posttest design have been evaluated as findings regarding the effect of the environment on reflective thinking skills. While getting the participants' opinions related to the environment, a receiving opinion questionnaire consisting of open ended questions and developed by researchers has been used.

The answers have been evaluated and commented with content analysis. 38 students and 4 researchers have enrolled in the environment. However, the data got from the 12 students answering data collection tools thoroughly has been analysed. The process has begun with a pretest related to the analysis of the class management problem. Afterwards, a different class management problem has been given and discussion has been asked. In the process of discussion, the chance of seeing each others' answers and giving answers to each other has been given the participants. Then, the problem given for the pretest has been given again and the changes in the answers have been investigated. The difference between the pretest and posttest has given clues regarding the possibility that the online environment improve the students' reflective thinking skills even though it is a very short term practice. It has been considered that the difference realised in the reflective thinking skills has been resulted from both the quality of the questions related to the problem and the ability of that each participant read others' answers. By this way, it can be possible to see the situations in really different aspects. Thus, it can be said that online environments carry an important potential power in the aspect of reflective thinking's improvement. The rearrangement of the developed online environment on the way of the opinions got from students, testing it with more sample groups and with the studies that will involve longer period of time have been considered. 